\title{
Pertumbuhan Kalus Jeruk JC (Japansche Citroen) pada Media Murashige and Skoog dengan Berbagai Konsentrasi $\mathrm{NaCl}$
}

\author{
Ika Dian Puspitasari, Wirdhatul Muslihatin, dan Dita Agisimanto \\ Departemen Biologi, Fakultas Ilmu Alam, Institut Teknologi Sepuluh Nopember (ITS) \\ Balai Penelitian Tanaman Jeruk dan Buah Subtropika (Balitjestro) \\ e-mail: agisimanto@gmail.com
}

\begin{abstract}
Abstrak-Jeruk JC (Japansche Citroen) merupakan salah satu jenis jeruk yang sering digunakan sebagai stok batang bawah. Batang bawah harus mampu tumbuh dan beradaptasi pada kondisi lingkungan yang kurang baik, salah satunya terhadap cekaman salinitas. Tujuan penelitian ini yaitu untuk mengetahui pengaruh media dengan konsentrasi $\mathrm{NaCl}$ yang berbeda terhadap pertumbuhan kalus jeruk JC (Japansche Citroen) secara in vitro. Eksplan berupa kalus jeruk JC diinokulasikan pada media MS cair dengan penambahan $\mathrm{NaCl}$ konsentrasi 0 $\mathrm{mM}, 50 \mathrm{mM}, 100 \mathrm{mM}$, dan $150 \mathrm{mM}$. Parameter pengamatan yang digunakan yaitu berat basah kalus. Data dianalisis menggunakan ANOVA One Way dan dilanjutkan dengan uji Tukey pada taraf kepercayaan $95 \%$. Berdasarkan hasil penelitian ini konsentrasi $\mathrm{NaCl}$ berpengaruh nyata terhadap pertumbuhan kalus jeruk JC. Pada konsentrasi $150 \mathrm{mM}$ kalus jeruk JC dapat bertahan hidup terhadap kondisi salinitas tinggi. Berat basah kalus tertinggi yaitu pada perlakuan kontrol sebesar $0,876 \mathrm{~g}$, sedangkan berat basah terendah yaitu sebesar $0,573 \mathrm{~g}$ pada perlakuan $\mathrm{NaCl}$ konsentrasi $150 \mathrm{mM}$.
\end{abstract}

Kata Kunci-Japansche Citroen, Kalus batang bawah, NaCl, Pertumbuhan kalus.

\section{PENDAHULUAN}

$\mathrm{J}_{\mathrm{p}}$ ERUK merupakan salah satu komoditas hortikultura yang penting, karena kandungan nutrisi dan fungsionalnya. Konsumsi segar dan olahan dari buah jeruk yang tinggi, menyebabkan nilai komersialnya menjadi daya tarik petani dan pedagang. Oleh karena itu konsumsi dan perdagangan jeruk selalu meningkat setiap tahunnya. Hal ini ditandai dengan semakin meningkatnya konsumsi jeruk di Indonesia dari tahun ke tahun. Konsumsi jeruk pada tahun 1995-2004 mengalami peningkatan sebesar $12,15 \%$ per tahun [1]. Total konsumsi buah jeruk di Indonesia pada tahun 2004 mencapai 2161,90 ribu ton, sedangkan produksi jeruk dalam negeri hanya 2071,08 ribu ton [2].

Produktivitas jeruk nasional beberapa tahun belakangan ini cenderung mengalami penurunan. Pada tahun 2011 produksi jeruk sebesar 1.721.880 ton menjadi 1.498 .394 ton pada tahun 2012, tahun 2014 produksi jeruk sebesar 1.785.256 ton menjadi 1.744.330 ton pada tahun 2015 [3]. Menurunnya produktivitas jeruk tersebut antara lain disebabkan oleh hama dan penyakit, terutama CPVD (Citrus Vein Phloem Degeneration) yang disebabkan oleh bakteri patogen [4], dan berkurangnya areal pertanaman yang subur akibat peralihan fungsi keluar sektor pertanian [5]. Penggunaan batang bawah pada budidaya (okulasi) tanaman jeruk yang kurang sesuai dengan batang atas dapat menjadi penghambat produksi tanaman [6].

Berbagai langkah dilakukan untuk meningkatkan produktivitas jeruk, antara lain perbaikan genetik batang bawah jeruk. Peran batang bawah dalam produktivitas tanaman jeruk sangat penting untuk mendukung pertumbuhan serta adaptasi pada kondisi lingkungan yang kurang baik. Batang bawah tanaman jeruk berperan dalam mencegah serangan penyakit pada akar, karena batang atas pada umumnya sangat peka terhadap penyakit tersebut. Batang bawah tanaman jeruk harus mempunyai kompatibilitas genetik yang tinggi dengan batang atas (scion), serta mempunyai sistem perakaran yang baik [7][8].

Jeruk JC (Japansche Citroen) (Citrus limonia Osbeck.) merupakan salah satu jenis jeruk yang sering digunakan sebagai batang bawah. Genotipe ini memiliki keunggulan jeruk tipe batang bawah yaitu tingkat kompatibilitasnya yang tinggi dengan batang atas dan sistem perakaran yang baik [9].

Pemuliaan batang bawah jeruk untuk ketahanan dan toleran terhadap cekaman abiotik di lahan marginal merupakan salah satu prioritas. Lahan marginal adalah lahan yang mempunyai potensi rendah sampai sangat rendah yang masih dapat dimanfaatkan sebagai lahan pertanian, misalnya lahan pasang surut, lahan salin, gambut, dan lahan yang berada di dekat areal pertambangan [7]. Salinitas merupakan cekaman abiotik yaitu kondisi tanah yang ditandai dengan konsentrasi garam terlarut yang tinggi [10]. Salinitas menjadi salah satu faktor pembatas yang mampu menyebabkan menurunnya pertumbuhan dan produktivitas tanaman, serta pada konsentrasi tertentu dapat mengakibatkan kematian tanaman [11][12].

Berbagai metode digunakan untuk mendapatkan tanaman dengan ketahanan/toleransi terhadap cekaman abiotik. Metode secara in vitro digunakan untuk mengetahui respon kalus terhadap cekaman salinitas. Metode ini mudah dimodifikasi untuk pertumbuhan eksplan pada kondisi kadar garam dengan konsentrasi tertentu yang diharapkan dapat menimbulkan stres pada eksplan. Kondisi tersebut akan merubah pola metabolisme sel kalus sehingga sel mampu berproliferasi dan bertahan pada kondisi dibawah tekanan kadar garam [13].

Penelitian ini bertujuan untuk mengetahui pengaruh media dengan konsentrasi $\mathrm{NaCl}$ yang berbeda terhadap pertumbuhan kalus jeruk JC (Japansche Citroen) secara in vitro. 


\section{METODOLOGI}

\section{A. Pembuatan Media}

Media MS dimasukkan ke dalam gelas beker, diikuti dengan $10 \mathrm{ml}$ vitamin dan $100 \mathrm{mg} / \mathrm{L}$ myo inositol. Sumber karbon yang digunakan adalah sukrosa dengan konsentrasi 30 $\mathrm{g} / \mathrm{L}$. Media dibagi dalam 4 gelas beker dengan volume yang sama. Setiap media ditambahkan $\mathrm{NaCl}$ dengan kombinasi konsentrasi $0\left(\mathrm{Cl}_{1}\right), 50\left(\mathrm{Cl}_{2}\right), 100\left(\mathrm{Cl}_{3}\right)$ dan $150 \mathrm{mM}\left(\mathrm{Cl}_{4}\right)$. Medium direbus hingga mendidih selama 5-10 menit, dan ditambahkan aquades sampai volume $250 \mathrm{~mL}$ setiap jenis media. Medium dihomogenkan menggunakan magnetic stirer kemudian diikuti dengan penetapan $\mathrm{pH}$ pada kisaran 5.7-5.8 dengan penambahan $\mathrm{NaOH}$ atau $\mathrm{HCl}$. Medium dengan volume $25 \mathrm{~mL}$ dimasukkan ke dalam erlenmeyer, ditutup dengan alumnium foil dan plastik wrap. Semua medium dimasukkan ke dalam autoklaf untuk disterilisasi selama 10 menit pada suhu $121^{\circ} \mathrm{C}$

\section{B. Inokulasi Kalus Pada Media}

Eksplan berupa kalus jeruk JC ditimbang sebanyak $125 \mathrm{mg}$ dan dimasukkan ke dalam setiap erlenmeyer pada media dengan konsentrasi $\mathrm{NaCl}$ yang berbeda, media $\mathrm{Cl}_{1}(0 \mathrm{mM}), \mathrm{Cl}_{2}$ $(50 \mathrm{mM}), \mathrm{Cl}_{3}(100 \mathrm{mM})$, dan $\mathrm{Cl}_{4}(150 \mathrm{mM})$. Media yang telah berisi kalus di letakkan pada rotary shaker dengan kecepatan 50-75 rpm.

\section{Peremajaan Media}

Peremajaan media dilakukan setiap 2 minggu sekali setelah dilakukannya pengamatan kalus jeruk JC. Media cair dalam erlenmeyer dibuang dan diganti media baru dengan komposisi media yang sama dengan media awal.

\section{Pengamatan Pertumbuhan Kalus}

Pengamatan pertumbuhan kalus dilakukan pada awal inokulasi dan setiap 2 minggu hingga 12 minggu. Variabel yang diamati adalah berat basah kalus. Berat basah kalus dihitung dengan cara menimbang berat segar kalus akhir (Final growth).

\section{E. Rancangan Penelitian dan Analisis Data}

Rancangan penelitian yang digunakan adalah Rancangan Acak Lengkap (RAL) dengan satu faktor yaitu konsentrasi $\mathrm{NaCl}$ pada media dan dilakukan pengulangan sebanyak 10 kali.

Data yang diperoleh dari hasil pengamatan akan dianalisis menggunakan ANOVA One Way untuk mengetahui pengaruh konsentrasi $\mathrm{NaCl}$ yang berbeda pada media terhadap pertumbuhan kalus jeruk JC (Japansche Citroen).

Hipotesis yang digunakan sebagai berikut:

$\mathrm{H}_{0}$ : Konsentrasi $\mathrm{NaCl}$ tidak berpengaruh terhadap pertumbuhan kalus jeruk JC (Japansche Citroen).

$\mathrm{H}_{1}$ : Konsentrasi $\mathrm{NaCl}$ berpengaruh terhadap pertumbuhan kalus jeruk JC (Japansche Citroen).

Jika $\mathrm{H}_{0}$ ditolak atau konsentrasi $\mathrm{NaCl}$ yang berbeda memberi pengaruh terhadap pertumbuhan kalus jeruk JC (Japansche Citroen), maka dilakukan uji Tukey pada taraf kepercayaan $95 \%(\alpha=0,05)$ untuk mengetahui besarnya perbedaan tiap perlakuan terhadap kontrol.

\section{PEMBAHASAN}

Perbedaan konsentrasi $\mathrm{NaCl}$ pada media tumbuh berpengaruh terhadap pertumbuhan kalus jeruk JC, hal ini dapat dilihat dari berat basah kalus (Gambar 1). Penambahan $\mathrm{NaCl}$ pada media merupakan perlakuan cekaman salinitas. Gambar 1 menunjukkan kalus jeruk JC pada semua perlakuan mengalami peningkatan berat basah dalam setiap minggunya sampai pada akhir pengamatan. Berat basah kalus tertinggi terjadi pada perlakuan kontrol yaitu sebesar 0,876 g, sedangkan berat basah terendah yaitu sebesar $0,573 \mathrm{~g}$ pada perlakuan $\mathrm{NaCl}$ dengan konsentrasi $150 \mathrm{mM}$ (Tabel 1).

Kalus jeruk JC mampu bertahan hidup pada media dengan konsentrasi $\mathrm{NaCl}$ tinggi $(150 \mathrm{mM})$, meskipun mengalami reduksi pertumbuhan pada perlakuan $\mathrm{NaCl}$ dibandingkan kontrol. [14], menyatakan bahwa adanya $\mathrm{NaCl}$ pada media menyebabkan cekaman salinitas serta dalam konsentrasi tertentu dapat menyebabkan penyerapan hara dan pengambilan air terhalang, sehingga menyebabkan pertumbuhan lambat.

Penambahan $\mathrm{NaCl}$ pada media menyebabkan sel-sel pada tanaman melakukan regulasi dalam metabolismenya sehingga mampu bertahan hidup dalam kondisi cekaman salinitas [13]. Mekanisme adaptasi yang dilakukan oleh sel saat tercekam $\mathrm{NaCl}$ adalah dengan mengakumulasi ion-ion organik seperti betain, asam amino bebas, karbohidrat terlarut dan prolin atau senyawa dengan berat molekul yang rendah [15]. Senyawasenyawa tersebut memberikan perlindungan pada tanaman dari dampak cekaman melalui mekanisme yang berbeda, yakni keseimbangan osmotik seluler, detoksifikasi Reactive Oxygen Species, menjaga integritas membran dan menstabilkan enzim atau protein [16]. Sehingga kalus tetap dapat tumbuh pada kondisi cekaman salinitas.

Berdasarkan hasil analisis ANOVA One Way yaitu $\mathrm{p}$ value sebesar 0,000 ( $\mathrm{p}$ value < 0,05), menunjukkan bahwa perlakuan konsentrasi $\mathrm{NaCl}$ berpengaruh terhadap pertumbuhan kalus jeruk JC dengan indikator berat basah kalus. Selanjutnya, dilakukan uji Tukey untuk mengetahui perbedaan nyata antar perlakuan terhadap berat basah dengan hasil analisis menunjukkan terdapat perbedaan nyata antar perlakuan. Pada tabel 1 terdapat perbedaan berat basah kalus antara media tanpa $\mathrm{NaCl}$ (kontrol) dan media dengan $\mathrm{NaCl}$. Penambahan $\mathrm{NaCl}$ ke dalam media tumbuh dengan konsentrasi $50 \mathrm{mM}, 100$ $\mathrm{mM}$, dan $150 \mathrm{mM}$ menyebabkan pertumbuhan kalus lebih rendah dibandingkan kontrol. Meskipun demikian berat basah kalus pada konsentrasi $50 \mathrm{mM}, 100 \mathrm{mM}$, dan $150 \mathrm{mM}$ tidak menunjukkan perbedaan berat basah yang signifikan.

Pertumbuhan kalus yang menurun pada tiap perlakuan diyakini merupakan pengaruh langsung cekaman salinitas karena adanya $\mathrm{NaCl}$ pada media. Penurunan berat basah kalus pada konsentrasi $\mathrm{NaCl}$ yang semakin tinggi dikarenakan kalus mengalami cekaman salinitas, sehingga menginduksi stres osmotik, yang berdampak pada pertumbuhan sel [17]. Pertumbuhan kalus jeruk JC mengalami reduksi dengan penambahan konsentrasi $\mathrm{NaCl}$ pada media. Kondisi ini umum terjadi pada berbagai peristiwa cekaman salinitas. Berbagai penyebab penurunan pertumbuhan dijelaskan dalam berbagai laporan [18][19][20] dan [21]. 


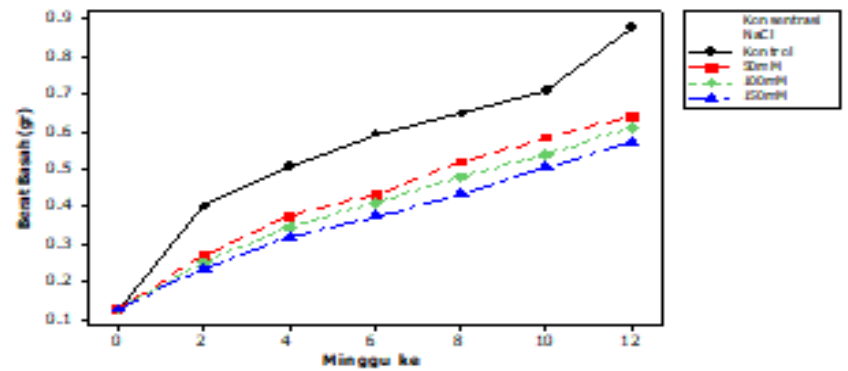

Gambar 1. Grafik berat basah kalus jeruk JC.

Pada kondisi cekaman salinitas terjadi penghambatan metabolisme akibat gangguan ketidakseimbangan ion dan efek osmotik, sehingga sel membutuhkan energi lebih untuk melakukan metabolisme dan berpengaruh terhadap penurunan pertumbuhannya [22] dibandingkan tanpa cekaman salinitas [17][19]. Energi yang dihasilkan lebih banyak digunakan untuk mengatur penyesuaian osmotik dan berdampak pada penurunan berat basah kalus [23], selain itu adanya cekaman salinitas dengan konsentrasi tertentu dapat menyebabkan pertumbuhan abnormal atau lambat [24].

Berlebihnya kandungan $\mathrm{Na}^{+}$dan $\mathrm{Cl}^{-}$dapat menghambat asimilasi Nitrogen yakni penyerapan nitrat $\left(\mathrm{NO}_{3}^{-}\right)$dimana penting untuk pertumbuhan tanaman [25]. Cekaman salinitas juga dapat menurunkan tingkat $\mathrm{K}^{+}$dan $\mathrm{Ca}^{2+}$, dimana ion $\mathrm{Na}^{+}$ mengalami peningkatan. Telah dilaporkan oleh [26] bahwa ion $\mathrm{K}^{+}$dan $\mathrm{Ca}^{2+}$ berperan penting dalam mempertahankan keseimbangan osmotik. Menurut [14], tingginya kandungan ion $\mathrm{Na}^{+}$dalam sel menghambat pengambilan $\mathrm{K}^{+}$yang menyebabkan peningkatan rasio ion $\mathrm{Na}^{+} / \mathrm{K}^{+}$, sehingga keseimbangan ion pada sel akan terganggu dan akan berdampak pada terganggunya hingga kerusakan struktur serta fungsi integritas membran. Pada kondisi tersebut, sel akan melakukan mekanisme untuk tetap berada dalam kondisi normal yaitu dengan mempertahankan rendahnya kadar garam pada sitoplasma [27][28]. Hal ini dilakukan dengan mentransferkan ion $\mathrm{Na}^{+}$ke dalam vakuola [29][30][13][31] dan [32], dimana vakuola merupakan tempat utama penyimpanan garam pada tanaman terhadap kondisi salinitas [33].

\section{KESIMPULAN}

Kesimpulan penelitian ini adalah konsentrasi $\mathrm{NaCl}$ berpengaruh nyata terhadap pertumbuhan kalus jeruk JC. Pada konsentrasi $150 \mathrm{mM}$ kalus jeruk JC dapat bertahan hidup terhadap kondisi salinitas tinggi. Berat basah kalus tertinggi yaitu pada perlakuan kontrol sebesar 0,876 g, sedangkan berat basah terendah yaitu sebesar 0,573 g pada perlakuan $\mathrm{NaCl}$ dengan konsentrasi $150 \mathrm{mM}$.

\section{DAFTAR PUSTAKA}

[1] B. Hutabarat and A. Setyanto, "Komoditas Jeruk Indonesia di Persimpangan Jalan Pasar Domestik dan Internasional," in Prosiding Seminar Nasional Jeruk, 2007.

[2] Departemen Pertanian, "Prospek dan Arah Pengembangan Agribisnis Jeruk Tahun 2004," 2009. .
Tabel 1.

Pengaruh $\mathrm{NaCl}$ terhadap berat basah kalus

\begin{tabular}{cc}
\hline \hline Perlakuan & Berat basah kalus $(\mathrm{g})$ \\
\hline $0 \mathrm{mM}$ & $0,876^{\mathrm{a}}$ \\
$50 \mathrm{mM}$ & $0,640^{\mathrm{b}}$ \\
$100 \mathrm{mM}$ & $0,610^{\mathrm{b}}$ \\
$150 \mathrm{mM}$ & $0,573^{\mathrm{b}}$
\end{tabular}

Keterangan: Huruf yang sama menunjukkan tidak berbeda nyata berdasarkan uji Tukey dengan tingkat kepercayaan $95 \%(\alpha=0,05 \%)$.

[3] [BPS] Badan Pusat Statistika, "Data Luas panen, Produksi, dan Produktivitas Jeruk," 2015.

[4] M. Garnier, S. Jagoueix, L. P. R. Cronje, H. F. Roux, and J. M. Bove, "Genomic Characterization of a Litobacter Present in an Ornamental Rutaceus Tree. Clodendrum Capense, in Western Cape Province of South Africa. Proposal a Candidatus Liberobacter africanum Subsp. Capensis," Int. J. Syst. Evol. Microbiol., vol. 50, pp. 2119-2125, 2000.

[5] Martias, "Respon Pertumbuhan Bibit Jeruk JC terhadap Pemberian CaCO3 dan Pupuk P Pada Tanah Ultisol," J. Hortik., vol. 14, no. 1, pp. 33-40, 2004

[6] Karmanah, "Peningkatan Ketahanan Batang Bawah Jeruk Pada Lahan Masam Melalui Kultur In Vitro," Institut Pertanian Bogor, 2009.

[7] M. Kosmiatin, A. Husni, R. Yunita, and C. Martasari, "Peningkatan Keragaman Genetik Pada Jeruk Batang Bawah untuk Ketahananan terhadap Lahan Masam (Genetic Diversity Improvement of Citrus Rootstock for Resistance on Acid Soil)," in Prosiding Seminar Nasional Jeruk, 2007, pp. 219-227.

[8] N. F. Devy, A. Sugiyanto, and F. Yulianti, "Daya Tumbuh Tanaman Jeruk Kalamondin Hasil Perbanyakan via Somatik Embriogenesis In Vitro pada Batang Bawah JC," J. Hortik., vol. 21, no. 3, pp. 214-224, 2011.

[9] R. Triatminingsih and Karsinah, "Perbanyakan Bibit Jeruk Citromelo dan JC secara In Vitro," J. Hortik., vol. 14, no. 4, pp. 238-245, 2004.

[10]R. Munns and M. Tester, "Mechanisms of Salinity Tolerance," Annu. Rev. Plant Biol, vol. 59, pp. 651-681, 2008.

[11]J. T. Flowers, "Improving Crop Salt Tolerance," J. Exp. Bot, vol. 396, no. 55, pp. 307-319, 2004.

[12]M. R. Foolad, "Recent Advances in Genetics of Salt Tolerance in Tomato," Plant Cell. Tissue Organ Cult., vol. 76, pp. 101-119, 2004.

[13]S. Yokoi, A. B. Ray, and M. H. Paul., "Salt Stress Tolerance of Plant. JIRCAS Working Report Center of Environmental Stress Physiology," Japan, 2002.

[14]J. Summart, P. Thanonkeo, S. Panichajakul, P. Prathepha, and M. Mcmanus, "Effect of Salt Stress on Growth, Inorganic Ion and Proline Accumulation in Thai Aromatic Rice, Khao Dawk Mali 105, Callus Culture," African J. Biotechnol, vol. 9, pp. 145-152, 2010.

[15]W. Al-Shorafa, A. Mahadeen, and K. Al-Absi, "Evaluation for Salt Stress Tolerance in Two Strawberry Cultivars," Am. J. Agric. Biol. Sci, vol. 9, no. 3, pp. 334-341, 2014.

[16]E. Ramezani, M. G. Sepanlou, and H. A. B. Naghdi, "The Effect of Salinity on The Growth, Morphology and Physiology of Echium amoenum Fisch. \& Mey," African J. Biotechnol, vol. 10, no. 4, pp. 87658773, 2011.

[17]C. Ghoulam, A. Foursy, and K. Fares, "Effects of Salt Stress on Growth, Inorganic Ions and Proline Accumulation in Relation to Osmotic Adjustment in Five Sugar Beet Cultivars," Environ. Exp. Bot, vol. 47, no. 1, pp. 39-50, 2002.

[18]H. H. Khuder and Y. I. H. Al-Taei, "Effect of Salt Stress On Some Growth Indicators and Cellular Components of Wheat (Triticum aestivum L.) Callus," Int. J. Appl. Agric. Sci, vol. 1, no. 4, pp. 91-94, 2015.

[19]R. Yunita, N. Khumaida, D. Sopandie, and I. Mariska., "Growth and Regeneration of Rice (Oryza sativa L.) Callus in Salt Medium," Biosci. Res, vol. 11, no. 1, pp. 04-09, 2014.

[20]Z. N. Al Hattab, M. S. Hamdalla, and A. M. Mohammed, "Salinity Effect on Wheat Triticum aestivum L. Callus Growth and Development," Int. J. Multidiscip. Curr. Res, vol. 3, pp. 1185-1188, 2015.

[21] V. Y. Patade, P. Suprasanna, and V. A. Bapat, "Effects of Salt Stress in Relation to Osmotic Adjustment on Sugarcane (Saccharum officinarum L.) Callus Cultures," Plant Growth Regul, vol. 55, pp. 169-173, 2008. 
[22]I. W. A. Ubudiyah and T. Nurhidayati, "Respon Kalus Beberapa Varietas Padi (Oriza sativa L.) pada Kondis Cekaman Salinitas $(\mathrm{NaCl})$ secara in Vitro," J. Sains dan Seni Pomits, vol. 2, no. 2, pp. 138-143, 2013.

[23] S. Babu, A. Sheeba, P. Yogameenakshi, J. Anbumalarmathi, and P. Rangasamy, "Effect of Salt Stress in The Selection of Salt Tolerant Hybrids in Rice Under In vitro and In vivo condition," Asian J. Plant. Sci, vol. 6, no. 1, pp. 137-142, 2007.

[24] M. Pessarakli, "Dry Matter Yield, Nitrogen-15 Absorption, and Water Uptake by Green Bean under Sodium Chloride Stress," Crop. Sci, vol. 31, pp. 1633-1640, 1991.

[25]R. Yuniati, "Penapisan Galur Kedelai Glycine max (L.) Merrill Toleran terhadap $\mathrm{NaCl}$ untuk Penanaman di Lahan Salin," Makara Sains, vol. 8, no. 1, pp. 21-24, 2004.

[26]D. D. Hirschi, "The Calcium Conundrum, Both Versatile Nutrient and Specific Signal," Plant Physiol, vol. 136, pp. 2438-2442, 2014.

[27]D. Schachtman and W. Liu, "Molecular Pieces To The Puzzle of The Interaction Between Potassium and Sodium Uptake in Plants," Trends Plant Sci, vol. 4, pp. 281-287, 1999.

[28]P. M. Hasegawa, R. A. Bressan, K. J. Zhu, and J. H. Bohnert, "Plant
Cellular and Molecular Responces to High Salinity," Ann. Rev. Plant Physiol, vol. 51, pp. 463-499, 2000.

[29]E. Blumwald, G. S. Aharon, and M. P. Apse, "Sodium Transport in Plant Cells," Biochim. Biophys. Acta, vol. 1465, pp. 140-151, 2000.

[30]B. S. Wang, U. Luttge, and R. Ratajczak, "Effects of Salt Treatment and Osmotic Stress on V-ATPase and V-PPase in Leaves of The Halophyte Suaeda Salsa," J. Exp. Bot, vol. 52, no. 365, pp. 2355-2365, 2001.

[31] J. K. Zhu, "Regulation of Ion Homeostasis Under Salt Stress," Curr. Opin. Plant Biol, vol. 6, pp. 441-445, 2003.

[32]Q. S. Qiu, OY. Guo, F. J. Quintero, K. S. S. J. M. Pardo, and J. K. Zhu., "Regulation of Vacuolar Na+/H+ Exchange in Arabidopsis thaliana by The Salt Overly Sensitive (SOS) Pathway," J. Biol. Chem, vol. 279, pp. 207-215, 2004.

[33]I. Nemati, F. Moradi, S. Gholizadeh, E. S. Mortazavi, and M. Omidi, "Vacuolar Compartmentation of Solutes in Meristematic Cells and Protoplasts of Salt Sensitive and Tolerant Cultivars of Rice (Oryza sativa L.) Determined by Vacuolar Volume Changes," Intl. J. Agric. Crop. Sci, vol. 4, no. 6, pp. 310-316, 2012. 